\title{
着地動作における䌅衝的運動調節について
}

\author{
永田晨* 室增 男** 日 丸哲也***

\section{MOTOR CONTROL OF LANDING MOTION ON KINETIC ANALYSES ABOUT ABSORBABILITY}

\author{
Akira Nagata, Masuo Muro and Tetsuya Himaru
}

\begin{abstract}
The impulsive force-external loads relationships are reported experimentally on eight adult males by the method providing different actions : soft and hard motion or attached spring on the platform, four jumping down heights of the stand : 15, 33, 67 and $125 \mathrm{~cm}$ and four additional loads to the body weight : 1, 2, 4 and $8 \mathrm{~kg}$. The forces are dealed with as the momentum on the landing motion and apparatus used are multi-component forces plate and $16 \mathrm{~mm}$ camera. The impulsive force is measured using the planimeter about recorded waves of multicomponent forces exerted in the landing motion over the time of $0.8 \mathrm{sec}$. The results obtained are as follows;

1) The impulssive forces are increased on the relation of the logalithmic function proportionally with the height of stand and with the weight of load.

2) According to analyses of the landing motion, these angles of the ankle, the knee and the hip are flexed greater in proportion to heigher of the stand but no changes of these angles of body segments are showed with weighter of additional loads.

3) Taking these results and reference into consideration, absorbable landing motion has been assumed to involve decrement oscillation in internal body segments and to maintain potential using for the next motion.
\end{abstract}

(J. Physical Fitness Japan 1979, $28: 81 \sim 87$ )

\section{I. 緒 言}

生体の緩衝的運動調節を外部に発現された連動 現象の中で把え, その運動特徵とその発現メカ二 ズムの主要因子について考察する時に生体運動の 調節的機能の資料が得られるだろう。緩衝的な運 動の测定之評価は,「外力に対して生体が反応した 反溌力を運動量としてとらえ，その大小でもって 評価する」といえる。運動量の変化分は力積に等 しく，その時の運動状態を示すとすれば，緩衝能 の運動的評価は，その運動時の力積を测定して, その大小で評価されよう。従来てうした生体の緩 衝能についての研究はほとんどなく ${ }^{14)}$, 生体内の 緩衝的モデルとして記述されてきた。そのため, 生体諸器官の直列的弾性要素のつながりとして解
釈され，その機能が説明されてきた報告が多い。 緩衝能が最むよくあらわれると考えられる運動場 面は高所からの「とびおり着地動作」と考えられ る $^{9)}$ 。緩衝能测定上の妥当性として, 各種着地動 作をを测定することによって，独立したパフォーマ ンスを示しているので, 测定上着地動作の信頼性 や再現性も高いと考えられる。

本研究の目的は, 着地動作時に現われる緩衝能 を外部負荷の種類之質量によって, どの程度变化 するか, その程度と物体と生体との機能差を見出 すととにある。さらに物体の力学的な法則とは異 なる生体の緩衝的調節機能を見出す資料を集める ことである。普遍すれば, この解析によって, 生 体の運動機能発現法則と運動制御メカニズム解析 の基礎が得られるだろう。そして外部からの負荷

\footnotetext{
* 東京都站大学

** 東京薬科大学

Tokyo Metropolitan University

*** 文部省 
的な外乱をいかに巧みに制御するのか，その連動 琴象を着地動作の中で見い出そうとした。

\section{II. 方法}

1）着地動作の規定

被検者は可能な限り桑らかく，音を出さないよ うに，とびおり着地することを規定した。指定さ れた䇫所（足形で示す）に着地し，静止するよう に指示した。とびおり台前才 $30 \mathrm{~cm}$ に着地台が置 かれ，その台は金属（ステンレス）製のもので， 堅固なものである。床面の弾性は殆ど無視でき る。(四 1 参照)

2）着地動作時の運動量の测定

フォース・プレート（キスラー製）を使用し， ピエゾ効果による压電変化をチャージアンプにて 増幅する ${ }^{10)}$ 。それを電磁オシログラフに描出させ た。垂直，左右，前後力向（それぞれ Fz，Fx， Fy で示す)，そして垂南方向のトルクも测定し た。三方向の休反力波形の面積を求め（プラニメ ーターにて計算)，合算したものを着地動作時の 運動量とした。すなわち、 $\sqrt{\mathrm{Fz}^{2}+\mathrm{Fx}^{2}+\mathrm{Fy}^{2}}=$ $\mathrm{F}_{\mathrm{z}+\mathrm{x}+\mathrm{y}}$ で示されるように $\mathrm{F}_{\mathrm{z}+\mathrm{x}+\mathrm{y}}$ を求めて, 運 動量とした。なお，積分計算した時間は 0.8 秒に 区切った ${ }^{13)}$ 。

3）外部负獄

台高の変化と其に着地動作時の運動量が変化す
るので，ジャンプ台の高さを $15 \mathrm{~cm} \rightarrow 33 \mathrm{~cm} \rightarrow 67 \mathrm{~cm}$ $\rightarrow 125 \mathrm{~cm}$ とほぼ倍增の変化を与えた。位置のエネ ルギーが変化すれば，運動エネルギーも変化し， そして着地動作時の運動量にも変化を与えると考 え，次式を設定した。

$\mathrm{I}=\mathrm{W} \cdot \mathrm{v}$ (I：運動量, $\mathrm{W}$ : 重量, $\mathrm{v}$ : 落下速 度）この式のWを若干変化させるために体重に錘 りを付加する方法をとり, $1 \mathrm{~kg} \rightarrow 2 \mathrm{~kg} \rightarrow 4 \mathrm{~kg} \rightarrow$ $8 \mathrm{~kg}$ と增加させた。そのためにウェイト・スー ッを用いて，錘りを身体に密着させ，振動がおて らないように国定した。（これを加重と表現する）

4） $16 \mathrm{~mm}$ 映写機によるキネマティックス・ア ナリシス

外部負荷による動俳フォーム，すなわち落下フ オーム（とびおり動作）と着地フォームを身体各 関節部分の角度变化を中心に分析した。

5）被検者

着地動作可能な健常な男子 8 人を選んだ。平均 体重 $56.5 \mathrm{~kg}$, 平均身長 $166.4 \mathrm{~cm}$, 平均年令は 38 才 であった。

III. 結果

1）台高変化による緩衝的着地動作時の連動量 と身体各部分の角度变化

被検者小，典型的なデータ例として，4名を選 んで, 各被検者ごとの地地動時の連動量をまと

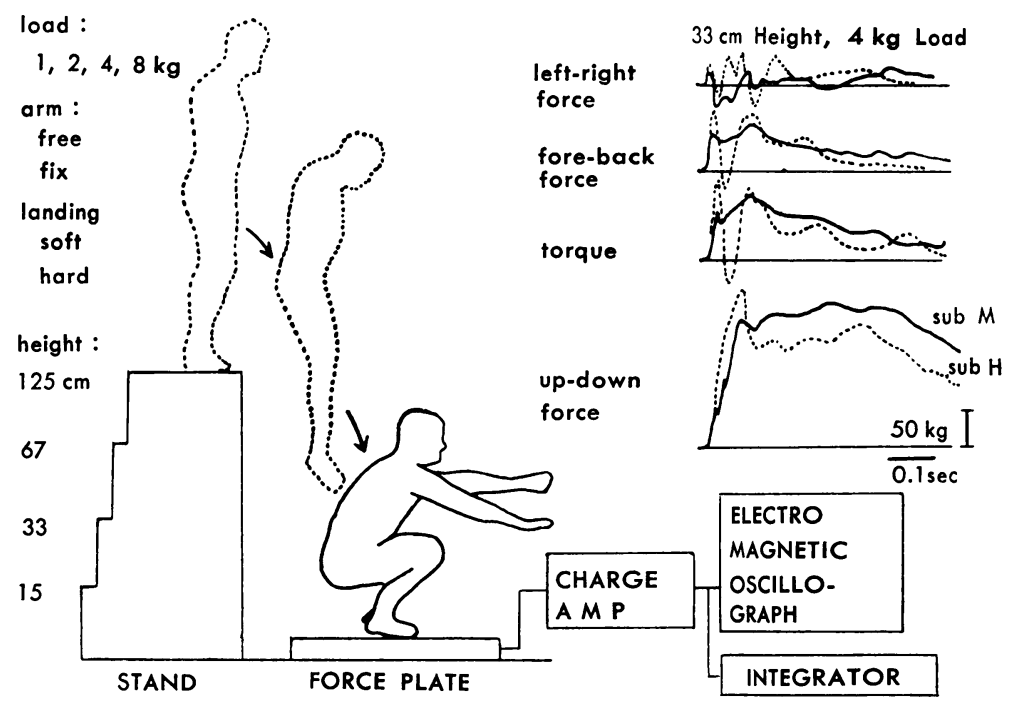

Fig. 1. Experimental system to analyze absorbability of landing motion 
FREE ARMS

NO LOAD

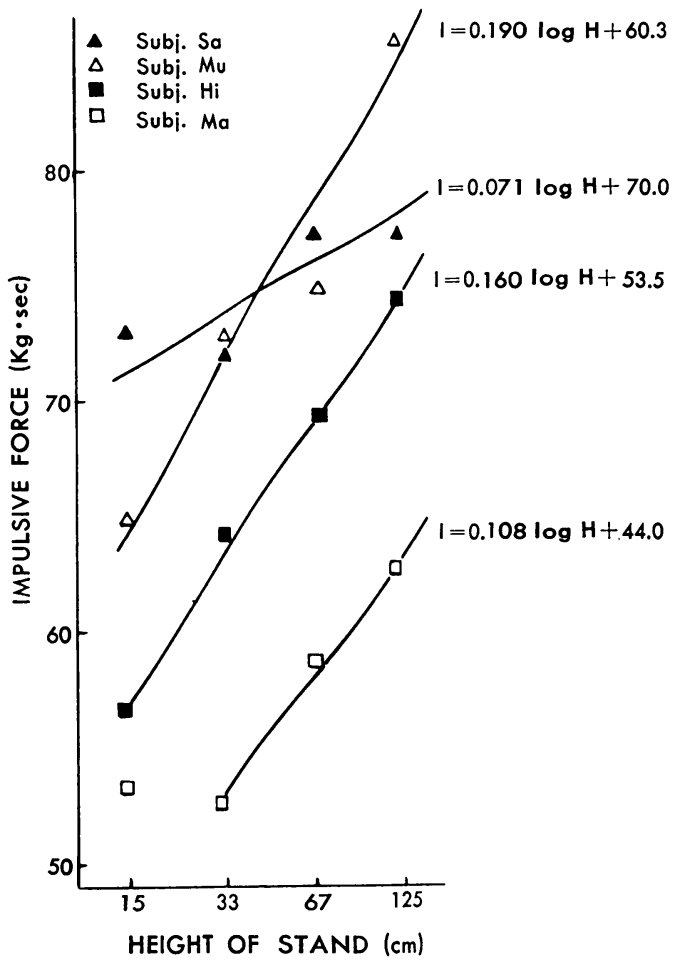

Fig. 2. Relationship between height of jumping down stand and the impulsive force
めたあのが図2である。身体各部分の角度変化を まとめたものが図 3 である。ジャンプ台高を 15 $\mathrm{cm}$ から $125 \mathrm{~cm}$ 一之倍增させ，その時の運動量 と角度変化をまとめた。

台高と運動量との関係を調へると, 被検者 Ma と $\mathrm{Sa}$ の回帰曲線は

$$
\begin{aligned}
\mathrm{I}_{\mathrm{Ma}}= & 0.108 \log \mathrm{H}+44.0 \\
& (\mathrm{I}: \text { 運動量, } \mathrm{H}: \text { 台高 }) \\
\mathrm{I}_{\mathrm{S}}= & 0.071 \log \mathrm{H}+70.0
\end{aligned}
$$

となり，少ない運動量と低い勾配を示した。

他方 $\mathrm{Hi}$ と Mu の回帰曲線は,

$$
\begin{aligned}
& I_{\mathrm{Hi}_{\mathrm{i}}}=0.160 \log \mathrm{H}+53.5 \\
& \mathrm{I}_{\mathbf{M}}=0.190 \log \mathrm{H}+60.3
\end{aligned}
$$

となり，多い運動量と高い勾配を示した。すべて の被検者沈いて, 緩衝的な柔らかい着地動作時 の運動量は, 台高の対数汇応じて比例的に変化す るととがわかった。

足许, 膝, 腰部に打ける角度变化は, 台高の変 化之其泟より一層身体各部分は深く曲代られ，角 度变化も大きくあらわれる傾向がある。特核被検 者 $\mathrm{Ma}$ と Sa の場合は, $67 \mathrm{~cm}$ の台高によって, 急激化大きくなる特徽をもっている。 $33 \mathrm{~cm}$ 台高 より $67 \mathrm{~cm}$ の倍增された時江身体各部分の対応

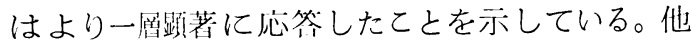

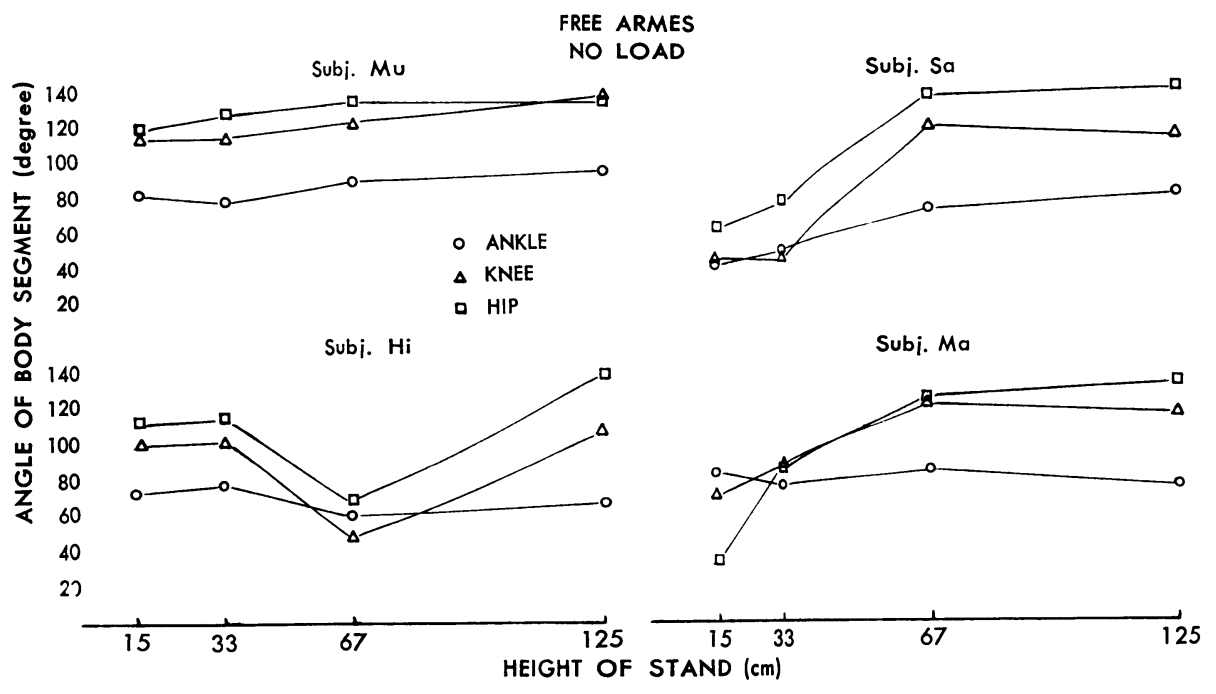

Fig. 3. Change of angles of ankle, knee and hip on effect of Height of stand 


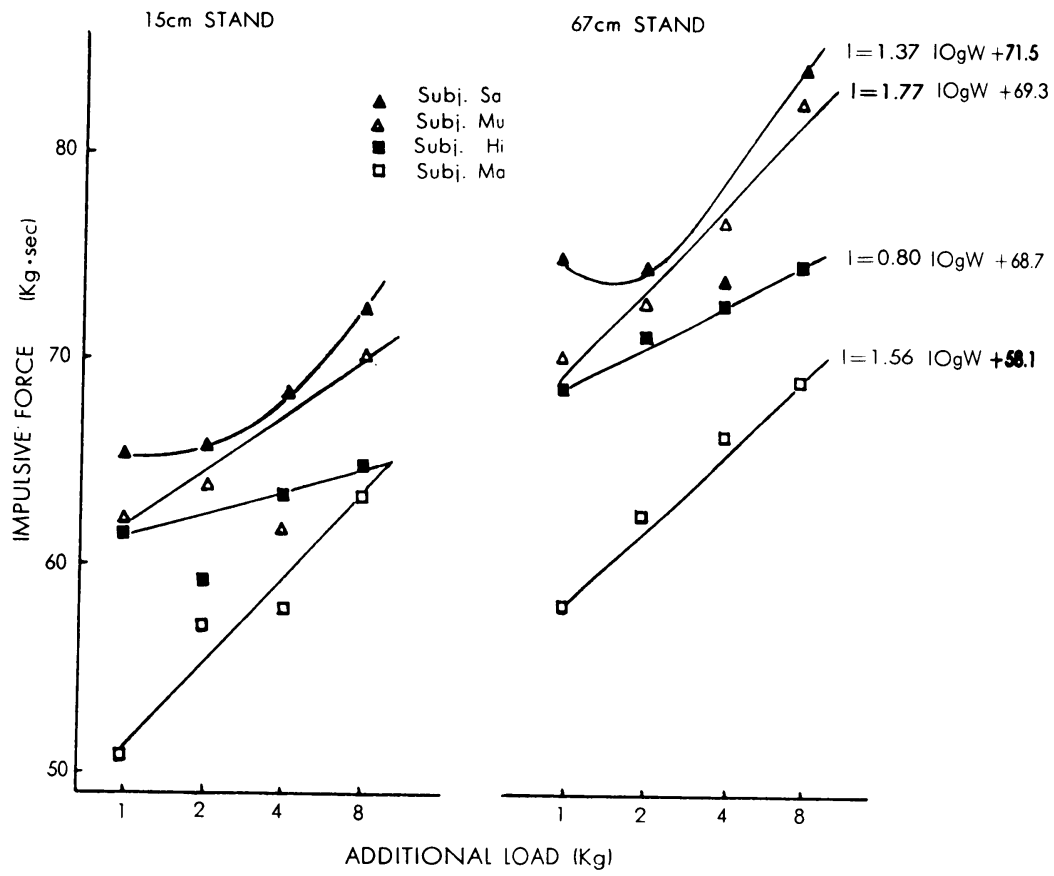

Fig. 4. Relationship between additional load to the body weight and impulsive force

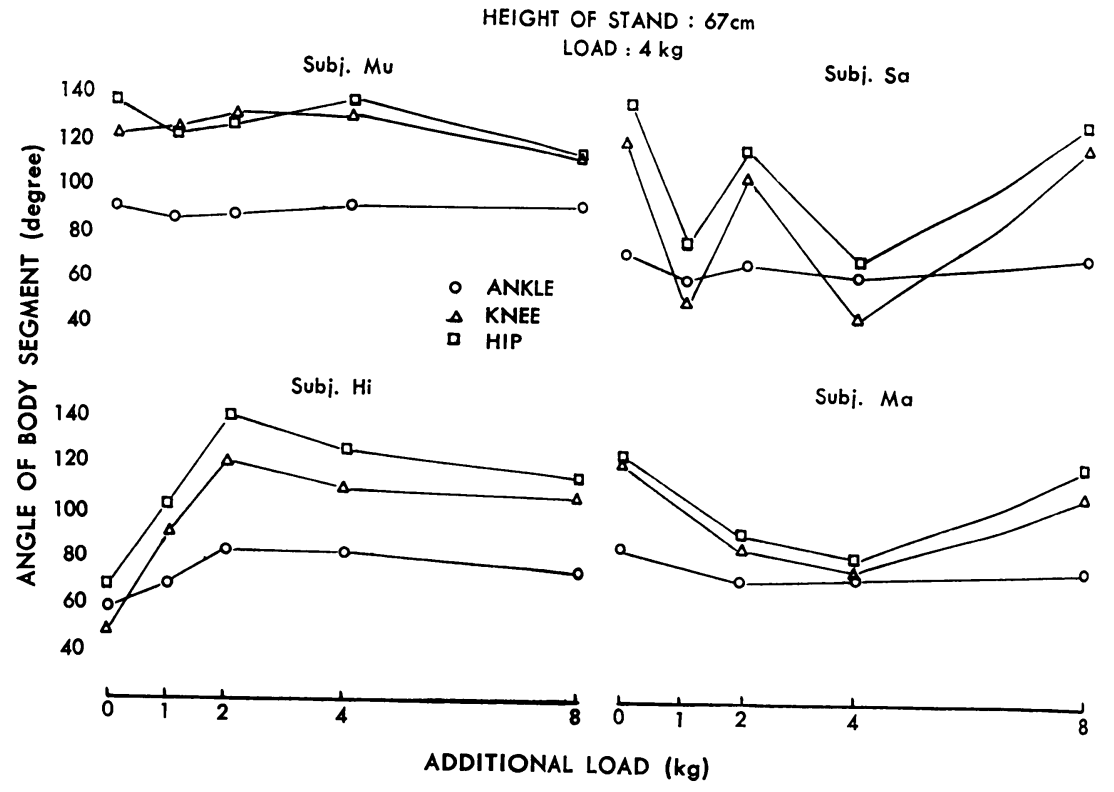

Fig. 5. Change of angles of ankle, knee and hip on effect of additional load 
才被検者 $\mathrm{Hi}$ の佮度変化が $67 \mathrm{~cm}$ 台高で逆飞減 少し, $\mathrm{Mu}$ の変化はあまり増加しなかった。

2）加重による緩衝的着地動作時の運動量と身 体各部分の伯度变化

外部から $1,2,4,8 \mathrm{~kg}$ の鍾りを付加し， 倍增変化された場合, 着地動作時の運動量と身体 各部分の们度変化をまとめた。

運動量については, $15 \mathrm{~cm}$ 台高と $67 \mathrm{~cm}$ 台高の 両条件時について図 4 にま之め, 佃度変化につい ては， $67 \mathrm{~cm}$ 台高の埸合のみ図 5 にまとめた。4 人の被検者について回帰曲線を算出した。その結 果, 加重の対数的変化に対応して, 運動量が整数 倍に変化するととがわかった。ただし，被検者 $\mathrm{Sa}$ のみ, 加重と運動量との関係は一次的な比例 直線を示した。その関係式は $67 \mathrm{~cm}$ 台高で, 被検 者 $\mathrm{Hi}$ と $\mathrm{Mu}$ の埸合

$$
\begin{aligned}
& I_{\mathrm{Hi}}=0.80 \log \mathrm{W}+68.7 \\
& \mathrm{I}_{\mathrm{Mu}}=1.77 \log \mathrm{W}+69.3
\end{aligned}
$$

を示した。

被検者 $\mathrm{Ma}$ と $\mathrm{Sa}$ の場合は,

$$
\begin{aligned}
& \mathrm{I}_{\mathrm{Ma}}=1.56 \log \mathrm{W}+58.1 \\
& \mathrm{I}_{\mathrm{Sa}}=1.37 \log \mathrm{W}+71.5
\end{aligned}
$$

の回帰式が得られ，いずれも前者のグループより も高い公配を示した。 $15 \mathrm{~cm}$ 台高の場合も同じ倾 向を示した。

$67 \mathrm{~cm}$ 台高の時の加重の変化と共に, 身体各部 分の角度は複雑に変化し, 一定の傾向を示さなか った。被検者 $\mathrm{Ma}$ と $\mathrm{Sa}$ は $4 \mathrm{~kg}$ 負荷の時に小さ い角度を示し，被検者 $\mathrm{Hi}$ は $2 \mathrm{~kg}$ 負荷のときに 大きい的度を示した。各被検者でとに加重によっ て, 着地フォームや各身体各部分の角度は大きく 変化した。加重による着地動作の変容は, 各個人 差が大きいととを示している。

\section{IV. 論}

1）着地動作の運動調䬦学的検討

柔らかく着地することは，床面上に与える運動 量を最小にすることであり，身体全体の緩衝能が 発見された埸合と考える。柔らかい着地のために 全身を使って動作しようとした場合，最も強調さ れるのが両腕の反動的な振り込みと㯟関節の屈曲 であろう。(図 $3 ， 5$ 参照) 本実験では，0.8秒の 時間的な力積を計算した結果であるから，0.1〜
0.2 秒の短侍間の場合には，別の様相を呈すると 思わ机る。Roy 等 ${ }^{13)} は ， 0.2$ 秒を 提唱している が，著者等は 0.8 秒によって，真の着地動作全体 を評価し得ると考える。着地動作の運動学的な解 釈は，床面に生体が触れた瞬間ではなく，その後 の動俳を含み, 着地時の衝撃力を柔らげる動作も 含むと解釈する ${ }^{11)}$ 。 $0.1 \sim 0.2$ 秒の短時間の力積で あれば，その床反力波形（特に垂直方向）の立ち 上り勾配や振幅值が大きくあらわれるに過ぎず, 着地動作の全体像が評価し難いと思われる。

2）着地動作侍の生体芯答について

本稿は, フォース・プレート上の着地動作で生 体は外部的に振動しないことを仮定した研究であ つた。しかし実際には身体内部の運動素子が振動 現象を起ししていると考えられる。実際の测定で も床面上での振動やは权返りはみられない。しか し, 関節部, 身体全体, 筋系の運動諸器官内で振 助現象が存在し，それは上肢や足首，膝関節が重 要な役目を任なっていると考元られる22。一部あ らわれている運動現促として，約 $2.5 \mathrm{~Hz}$ のおそい 振動波形が足の着地後にあらわれている。しかし 高い周波数の振動はみられなかった。外部にあら われた振動がないために理論的な運動量の計算に おいても反抁係数（e）を０とし，床面上に身体が 接触したままの状態を考えて，力積を計算してき た。すなわち，外面上非弾性的落下衝突の場合 で, 着地前後の速度は不変とした。物体と生体の 差を見出すために，物体の落下現象と生体の着地 動作とを比較してみた。物体が床面上に落下すれ ば必らず，振動現象が起てる。生体は外部的に振 動しないが，その硬さと弾性は床反力波形の勾配 で推察されよう6)。当然, 動的な硬さともいえる が，それに関与しているが，生体（主に関節部， 骨, 筋系)の弾性と推察される。乙れを裏付けるの は, 外部にスプリングを付加した侍の着地動作の 力積量の変化である ${ }^{4)}$ 。勿論, 身体内部で $2 \sim 3$ 度の振動現象は発しているだろう。物体では反拼 係数 (e) が存在し, 減衰振動をする ${ }^{3)}$ 。反揆係数 e は,

$$
\mathrm{e}=\sqrt{\frac{\mathrm{h}^{\prime}}{\mathrm{h}}}
$$

(h：最初の高さ, $\mathrm{h}^{\prime}$ ：次の高さ)

で示される。それがために物体は衝突後の速度に 
比例するわけであるが, 生体では, 着地後の速度 を同じとする1。

$$
\mathrm{e}=\frac{\mathrm{v}_{2}-\mathrm{v}_{1}}{\mathrm{u}_{1}-\mathrm{u}_{2}}
$$

ただし, $\mathrm{v}_{1}$ : 生体の落下速度

$\mathrm{v}_{2}:$ 生体の着地後の速度

$\mathrm{u}_{1}:$ 床面の着地前の速度

$\mathrm{u}_{2}$ : 床面の着地後の速度

この式より，分子は $\mathrm{v}_{2}=\mathrm{v}_{1}$ となり，分母は なって, 反溌係数 $\mathrm{e}$ は 0 となる。乙のような物体 の振動と比較して, はね返りを 0 とすることに䦓 題が生じ, 当然生体内部の諸器官で同じように減 衰振動的なは㸚返り現象が発生していると考えら れる ${ }^{15)}$ 。

3）緩衝的着地動作時の運動量と台高変化

着地動作ををずて来らかいとびおり動作に䍏定 し, ジャンプ台高を変化させながら，その時の迎 動量之足首, 滕, 腰部の角度変化を求め, 台高变 化に応じた連動量を調べた。その関係は対数的関 係にあり，一般的に，

$\mathrm{I}=\mathrm{A} \log \mathrm{H}+\mathrm{B}(\mathrm{I}:$ 連動量, $\mathrm{H}$ : 高さ)

で示される。すなわち, 連動量の発現は高さとい うパラメーターに対して，対数的な関係で作用す るといえる。運動量（力積, 仕事量, 整力) は, 台高によって比例的に変化し, 身体の運動機能の 発現様相を高さの要团から調へられる。

$$
\mathrm{I}=\mathrm{W} \cdot \sqrt{2 \mathrm{gh}} \quad(\mathrm{h}: \text { 高さ) }
$$

の運動方程式で示されるように，I と h とは二次 的な比例関係にある。しかし生体の落下着地実験 では, 高さ（h）と連動量（I）とは対数的な比例 関係にあるといえる。運動量は上記の式より， h の変化と共に I は h の 2 乘根で決まる。柔らかく 着地するために, 台高の増大は, 位置のポテンシ ヤルを增加させることになるので, 運動機能, 緩 衝的な運動調節上一種の外乱として作用する。乙 れをいかに巧みに吸収していくのかが課題となろ $j^{8)}$ 。

台高が整数倍に変化するに伴って, 連動量は刘 数的な加算によって増加する。抁言すると位置エ ネルギー（ポテンシャル）は增加しても，それに 比例した運動量の增大はみられない。すなわち, 身体は，エネルギーの一部を身体内部で保存する か, 吸収して, 全ポテンシャルを使用できないて とになる ${ }^{8)}$ 。ということは, 生体の保護と安全の
ために必要なととであり，高所からのとびおり動 作上必要な能力といえる。このような能力は, 生 体の特徵であり, 高い台高になればなるほど生理 学的な連動機能が介入できなくなり, 経験と訓練 によって可能な運動生理能力といえよう7)99。

4）運動量と加重の変化

外部に付加する鍾りの量を $1,2,4,8 \mathrm{~kg}$ を と整数倍增した場合, 着地動作時の運動量 $(0.8$ 秒間）は加重の対数倍に增加していった。ただ例 外として被検者 $\mathrm{Sa}$ の一式的な比例関係もみられ たが, 他の7名の被検者はすべて, 対数関係を示 した。 $\mathrm{I}=\mathrm{W} \cdot \sqrt{2 \mathrm{gh}}$ の式で，Wすなわち体重 に加重し，W'変化させた場合であり，I はW から W に增加したことによって，此例的に影響 を受ける。しかしながら上式の関係は生体の落下 着地動作時の場合には該当せず, 物体の比例関係 は生体の刘数関係に変わってきた。てれは，台高 の変化の場合と同㥞に，加重の增加は生体に大き な影摂を与元，鍕りの倍増に応じて生体の忍答が 不可能なととを示しているようである。すなわ ち, 加重增加によって, 生体は物体に近づく倾问 を示し，速動生理的な機能の発挫がみられないよ うである。

物体の場合は， $\mathrm{I}=\mathrm{W} \cdot \mathrm{v} （ \mathrm{v}$ : 落下速度）の式よ り, $\mathrm{W}$ が $\mathrm{W}^{\prime}$ と変化し, $\mathrm{I}^{\prime}=\mathrm{W}^{\prime} \cdot \mathrm{v}$ すなわち, $\mathrm{I}^{\prime}$ $=(\mathrm{W}+\mathrm{w}) \mathrm{v}\left(\mathrm{w}:\right.$ 加重鍾り) となり, $\mathrm{I}^{\prime}=\mathrm{Wv}+$ wv が導かれる6)。w の增加によって过動量 $\mathrm{I}^{\prime}$ は wv のみの加算で増加するにすぎない。他才生体 の運動量は $\mathrm{w}$ の錘り付加によって対数的に倍增 していく関係があり，生体と物体との差が著明で ある。これは生体にわずかの量の鍾りを制御しな がら着地することの難しさを示し， $8 \mathrm{~kg}$ の錘り では緩衝的な運動機能の発現が妨げられたととを 示すようである。換言すると加重によって，より 多くあらわれた運動量を生体内部で吸収するとと が不可能となったようである。 $1,2 \mathrm{~kg}$ 程度で あればその影響は少なく， $4 \mathrm{~kg}$ 以上の加重が限 界值ではなからうかと思われる。

\section{V. 要約}

柔らかい着地動作を実施し，その将の運動量を 休反力の力䅡加評価した。その結果, 外部に各 種の負荷を与え，すなわち，台高の变化と加重領 
りによってとびおり時の位置のエネルギーを増大 させた。そして, その時の運動量を測定し, 着地 動作:時の緩衝的運動機能の調節状態を観察した。 その結果, 次の要約を得た。

1） 0.8 秒間の着地動作侍の運動量によって, 生体の緩衝的な運動調邻状態が考察可能となっ た。

2）台高の対数的な変化とともに，着地動作㬨 の運動量は比例的に変化し, I=A log $\mathrm{H}+\mathrm{B}$ の回 州式で表現された。そして, 足前, 㯟, 腰部の角 度は, 台高の増大とともに大きく屈曲していっ た。

3）外部に錘りを付加するてとによって，その 量の対数変化に応じて運動量が変化し, $\mathrm{I}=\mathrm{A} \log$ $(\mathrm{W}+\mathrm{w})+\mathrm{B}$ の回帰式で表現された。

4）着地動作侍の身体各部分の角度変化は, 錘 り付加とともに一定の变化を示さず, 複雑な身体 フォームを発現した。そして錘り付加によって着 地動作の個人美を增大させていった。

5）着地動作において，外部に現われる振動は 倠察されなかった。

6）物体と生体との落下実験比較から，生体は とびおり時の位置エネルギーをすべて運動エネル ギーに変挨しなかった。

7）生体外部に鍾りを付加し，台高を增加させ るととによって, 理論值以上に大きな力積があら 机た。

（受付 昭和54年 2 月 23 日）

\section{参考文献}

1) Alexander, R.McN. and Goldspink, G. (1977): Mechanics and energetics of animal locomotion. Chapman and Hall, London, 168-203.

2) Cappozzo, A., Figura, F., Leo, T., and Marchett, M. (1978) : Biomechanical evaluation of above-knee prostheses. Biomechanics V-A, University Park Press, London, 366-372.

3) Feynman, R.P., Leighpon, R.B. and Sands, M.L., (1977) : 力学:, 快井忠二詮, 9 版, 岩波, 東京.

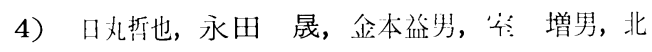
标拓 (1974)：とび抢り動作の着地㭙 shock の研劣 (1)一綬徱作用の過程について一, 束宗 都立大学体育学研究室紀要, 5, 29-36.

5) Jansen, E.C. and Jansen, K.F., (1978) : Visvelocitas-via : alteration of foot-to-ground torces during increasing speed of gait. Biomechanics Vl-A, University Park Press, London, 267-271.

6) 㠴内賢信 (1976) : 物理学, 九善, 東宗.

7) Lauru, L., (1957) : Physiological study ot motion. Advan. Manage., 22, 17-24.

8）宮地力, 小林一敏, 大岛義晴(1978): 着地動 作の力学的考察, 第 4 回キネシオロジーセミナ 一曰演资料.

9) Miller, D.I. and Nelson, R.C., (1973) : Biomechanics of sport. Lea and Febiger, Philadelphia, 53-61.

10) Payne, A.H., Slater, W.J., and Telford, T., (1968): The use of a force platform in the study of athletic activities. A preliminary in vestigation, Ergonomics. 11, 123-143.

11) Ramey, M.R. (1970) : Force relationships of the running long Jump. Med. Sci. Sports, 2. 146-151.

12) Ramey, M.R. (1973) : Use of force plates for long-Jump studies. Medicine and Sport, Biomechanics, III, University Park Press, London, 370-380.

13) Roy, B., Youm, Y. and Roberts, E.M.(1973): Kinematics and Kinetics of the standing long jump in $7,10,13$ and 16 year old boys. Medicine and Sport, Biomechanics, III, University Park Press, London, 409-416.

14）条利 缚, 下駄忠li（1976）: 調整力の指標とし ての悢衝能の発羊と綬衝能テストの検討, 体有 科学, 4, 142-149.

15）山下忠, 加藤了三，矢田部䊁义（1973）：直立 および歩行時での垂直力作用点の 移動パター ン, バイオメカニズム (2), 米京人学山版会, 313-320. 